\title{
Candidatus Neoehrlichia mikurensis and its co-circulation with Anaplasma phagocytophilum in Ixodes ricinus ticks across ecologically different habitats of Central Europe
}

\author{
Markéta Derdáková ${ }^{12^{*}}$, Radovan Václav ${ }^{1}$, Lucia Pangrácova-Blaňárová², Diana Selyemová ${ }^{1}$, Juraj Koči \\ Gernot Walder ${ }^{4}$ and Eva Špitalská ${ }^{3}$
}

\begin{abstract}
Background: Candidatus Neoehrlichia mikurensis is a newly emerging tick-borne bacterium from the family Anaplasmataceae. Its presence in Ixodes ricinus ticks was reported from various European countries, however, it's ecology and co-circulation with another member of the same family, Anaplasma phagocytophilum has not been rigorously studied yet.

Findings: Candidatus N. mikurensis was detected in all sampling sites. In total, $4.5 \%$ of ticks were positive including larvae. The highest positivity was detected in Austria with a prevalence of $23.5 \%$. The probability of Candidatus $\mathrm{N}$. mikurensis occurrence increased with the proportion of ticks infected with Anaplasma phagocytophilum.

Conclusion: A positive association between the occurrences of Candidatus N. mikurensis and A. phagocytophilum indicates that both bacteria share similar ecology for their natural foci in Central Europe.
\end{abstract}

Keywords: Candidatus Neoehrlichia mikurensis, Anaplasma phagocytophilum, Ixodes ricinus, Human granulocytic anaplasmosis, Neoehrlichiosis

\section{Findings}

In Europe, Candidatus N. mikurensis represents a newly emerging tick-borne zoonotic bacterium from the family Anaplasmataceae. Phylogenetic analyses revealed that it is closely related to the Ehrlichia-like microorganisms previously detected in ticks and rodents from various regions of Europe and Asia [1-6]. Recently its pathogenicity was reported, as it was detected in immunosuppressed patients with septicaemia [7-9]. Rodents are the competent reservoir hosts since they develop a systemic infection $[1,3,4,6]$ and are able transmit Candidatus N. mikurensis to the xenodiagnostic ticks [10]. The prevalence of Candidatus N. mikurensis in ticks over Europe varies, usually not exceeding 10\%. Most reports are from Western Europe

\footnotetext{
* Correspondence: marketa.derdakova@gmail.com

'Institute of Zoology, Slovak Academy of Sciences, Dúbravská cesta 9, 84506 Bratislava, Slovakia

${ }^{2}$ Institute of Parasitology, Slovak Academy of Sciences, Košice, Slovak Republic

Full list of author information is available at the end of the article
}

$[2,4,5,11]$. Recently it was reported in questing $I$. ricinus from Hungary [12] and Austria [13]. Here we report the prevalence of Candidatus N. mikurensis from 11 diverse ecological habitats from three Central European countries and its co-circulation in natural foci with Anaplasma phagocytophilum.

A total of 1535 (755 adults, 614 nymphs, 140 larvae, and 26 individuals for which the developmental stage was not identified) and 1413 (756 adults, 621 nymphs, 10 larvae, and 26 individuals for which the developmental stage was not identified) I. ricinus ticks from three Central European countries (Slovakia, the Czech Republic and Austria) (Figure 1) were tested for the presence of Candidatus N. mikurensis and A. phagocytophilum, respectively. Ticks were sampled from diverse habitats (Table 1) by blanket dragging. DNA was extracted from single individuals by DNeasy Blood \& Tissue Kit (Qiagen, Hilden, Germany). The presence of Candidatus N. mikurensis was detected by RT-PCR of groEL gene as described 


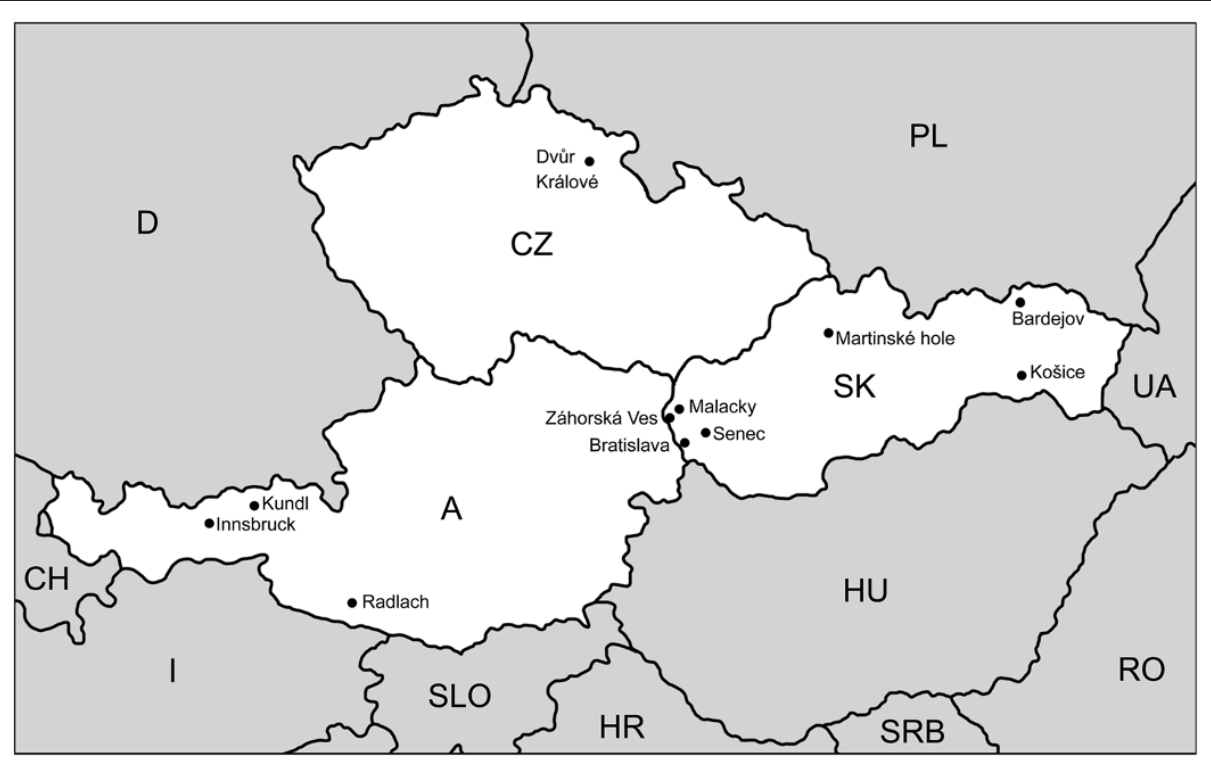

Figure 1 Map of sampling sites from Austria (A), Czech Republic (CZ) and Slovakia (SK); Central Europe.

before [4] or by nested PCR of the specific fragment of $16 \mathrm{~S}$ rRNA gene [1]. A. phagocytophilum was detected by RT-PCR of $m s p 2$ according to a previously described protocol [14] or by nested PCR amplifying the specific $546 \mathrm{bp}$ fragment of $16 \mathrm{~S}$ rRNA [15].

Candidatus N. mikurensis was detected in all 11 sampling sites. In total, 69 (4.5\%) of 1535 ticks were positive. The prevalence of Candidatus $\mathrm{N}$. mikurensis ranged from $1.1 \%$ to $23.5 \%$ (Table 1). In Austria at the site Kundl, Candidatus N. mikurensis was detected in 4 of 10 questing larvae.
In Total, 1413 ticks were tested for A. phagocytophilum and $53(3.8 \%)$ were positive. It was detected in all sampling sites, but one (Table 1). None of the tested larvae carried A. phagocytophilum.

Furthermore, we analyzed the relationship between the occurrence probability of Candidatus N. mikurensis and the proportion of ticks infected with A. phagocytophilum with a generalized linear mixed model (GLMM). The number of ticks infected with Candidatus N. mikurensis was entered as a dependent variable and was linked with a binomial error to the number of all ticks from a given

Table 1 Prevalence of Candidatus N. mikurensis (CNM) and A. phagocytophilum (AP) in I. ricinus ticks from sampling sites in Slovakia, the Czech Republic and Austria

\begin{tabular}{|c|c|c|c|c|c|}
\hline & $\begin{array}{l}\text { Geographical } \\
\text { coordinates }\end{array}$ & $\begin{array}{l}\text { Number of } \\
\text { ticks tested* }\end{array}$ & $\begin{array}{l}\text { Ca. N. mikurensis } \\
\text { positive (\%) }\end{array}$ & $\begin{array}{l}\text { A. phagocytophilum } \\
\text { positive (\%) }\end{array}$ & Habitat type and altitude \\
\hline Bratislava (SK) & $48^{\circ} 10^{\prime} \mathrm{N} 17^{\circ} 04^{\prime} \mathrm{E}$ & $378 / 248$ & $4(1.1)$ & $10(4)$ & Oak-beech, suburban and urban forests \\
\hline Senec (SK) & $48^{\circ} 16^{\prime} \mathrm{N} 17^{\circ} 21^{\prime} \mathrm{E}$ & 97 & $6(6.2)$ & $1(1)$ & Native fragmented, dry oak forest \\
\hline Malacky (SK) & $48^{\circ} 26^{\prime} \mathrm{N} 17^{\circ} 01^{\prime} \mathrm{E}$ & $93 / 101$ & $2(2.2)$ & $4(4)$ & Urban park with maples, oak hornbeam \\
\hline Záhorská Ves (SK) & $48^{\circ} 22^{\prime} \mathrm{N} 16^{\circ} 53^{\prime} \mathrm{E}$ & 121 & $14(11.6)$ & $5(4.1)$ & Farmland and pine lowland forest \\
\hline Martinské hole (SK) & $49^{\circ} 05^{\prime} \mathrm{N} 18^{\circ} 51^{\prime} \mathrm{E}$ & 219 & $7(3.2)$ & $6(2.7)$ & Mountain spruce forest \\
\hline Košice (SK) & $48^{\circ} 44^{\prime} \mathrm{N} 21^{\circ} 16^{\prime} \mathrm{E}$ & 224 & $6(2.7)$ & $10(4.5)$ & Oak-hornbeam urban forest \\
\hline Bardejov (SK) & $49^{\circ} 19^{\prime} \mathrm{N} 21^{\circ} 16^{\prime} \mathrm{E}$ & 179 & $8(4.5)$ & $3(1.7)$ & Oak, beech, maple, birch suburban \\
\hline Dvur Kralove (CZ) & $50^{\circ} 25^{\prime} \mathrm{N} 15^{\circ} 48^{\prime} \mathrm{E}$ & 138 & $3(2.2)$ & $8(5.8)$ & Mixed and pine suburban forest \\
\hline Austria total & & 86 & $19(22.1)$ & $6(7.0)$ & \\
\hline Innsbruck (AT) & $47^{\circ} 17^{\prime} \mathrm{N} 11^{\circ} 26^{\prime} \mathrm{E}$ & 26 & $5(19.2)$ & $3(11.5)$ & Mountain fir forest \\
\hline Kundl (AT) & $47^{\circ} 28^{\prime} \mathrm{N} 11^{\circ} 60^{\prime} \mathrm{E}$ & 51 & $12(23.5)$ & $3(5.9)$ & Beech-fir forest \\
\hline Radlach (AT) & $46^{\circ} 45^{\prime} \mathrm{N} 13^{\circ} 15^{\prime} \mathrm{E}$ & 9 & $2(22.2)$ & $0(0)$ & Alder and ash forest \\
\hline Total & & $1535 / 1413$ & $69(4.5)$ & $53(3.8)$ & \\
\hline
\end{tabular}

*If different numbers of ticks were analyzed for the presence of CNM and AP, two values (CNM/AP) are shown for the site (for Bratislava, 130 larvae were included in analysis for the presence of NM, but they were excluded in analysis for the presence of AP; for Malacky, not all ticks tested for CNM were tested for the presence of AP due to the lack of DNA. 
site and tick developmental stage. The proportion of ticks infected with $A$. phagocytophilum and the developmental stage of ticks were examined as fixed factors. As ticks for each site were examined at two developmental stages (nymphs and adults), site identity was entered as a random factor; three sampling sites from Austria were pooled due to sample size limitation. The probability of tick infection with Candidatus N. mikurensis increased with the proportion of ticks infected with $A$. phagocytophilum. The occurrence probability of Candidatus $\mathrm{N}$. mikurensis did not differ between adult and nymphal ticks (Table 2). The solutions of random effects revealed that the occurrence probability of Candidatus $\mathrm{N}$. mikurensis for the Austrian sites was significantly higher than the mean occurrence probability (estimate $\pm \mathrm{SE}=$ $1.08 \pm 0.43, \mathrm{t}_{6}=2.53, \mathrm{p}=0.039$ ).

We have confirmed the permanent circulation of Candidatus N. mikurensis and A. phagocytophilum in each of the three examined countries of Central Europe across a wide ecological spectrum of habitats (Table 1). The highest prevalence of Candidatus N. mikurensis (23.5\%) was observed in Austria. A similarly high prevalence (24.2-26.6\%) was found for questing ticks from Germany [16]. These are so far the highest prevalence results reported for Europe. Moreover, in Austria we have detected four positive questing larvae. Up to this date, the transovarial transmission has not been reported for Candidatus N. mikurensis. However, to our knowledge the questing larvae were examined for the pathogen only at one site in The Netherlands, by Jahfari et al. [4]. As the mode of pathogen transmission by vectors is of high epidemiological significance [17], possible transovarial transmission of Candidatus N. mikurensis should be elucidated in future studies.

The reservoir competency of rodents for Candidatus N. mikurensis have been recently confirmed [10]. As for

\begin{tabular}{|c|c|c|c|c|c|}
\hline Parameter & Estimate & SE & df & $t$ & $\bar{p}$ \\
\hline \multicolumn{6}{|l|}{ Random effect } \\
\hline Site ID & 0.49 & 0.32 & & & 0.128 \\
\hline \multicolumn{6}{|l|}{ Fixed effects } \\
\hline Intercept & -3.33 & 0.37 & 8 & -8.96 & $<0.001$ \\
\hline $\begin{array}{l}\text { Proportion of ticks } \\
\text { infected with AP }\end{array}$ & 7.02 & 2.69 & 7 & 2.61 & 0.035 \\
\hline $\begin{array}{l}\text { Tick developmental } \\
\text { stage_adults }\end{array}$ & -0.01 & 0.30 & 7 & -0.01 & 0.996 \\
\hline $\begin{array}{l}\text { Tick developmental } \\
\text { stage_nymphs }\end{array}$ & 0 & & & & \\
\hline
\end{tabular}

The pseudo-likelihood function was used to calculate parameter estimates. The analysis was conducted with SAS (SAS Institute Inc., Cary, NC) and the GLIMMIX macro.
A. phagocytophilum, it is unlikely that rodents are important reservoir hosts of the genotypes that are transmitted by I. ricinus. Based on the phylogenetic analyses of several genes, rodents in Europe are infected with distinct genotypes from that found in questing $I$. ricinus ([18], unpublished observation). Moreover, recent study showed that rodents infected with A. phagocytophilum were not able to transmit it to xenodiagnostic larvae [10]. The reservoir competence of other hosts for Candidatus $\mathrm{N}$. mikurensis needs to be elucidated, since it was detected in the ticks feeding on red deer, mouflon and wild boar [4].

\section{Conclusions}

We have revealed a positive association between the occurrences of Candidatus N. mikurensis and A. phagocytophilum. This finding indicates that both bacteria share similar ecology for their natural foci in Central Europe. This result has an important implication for public health, and patients with a history of tick bite should also be examined for the presence of Candidatus N. mikurensis since it is widespread throughout Central Europe in all regions where I. ricinus is present.

\section{Competing interests}

The authors declare that they have no competing interests.

\section{Authors' contributions}

MD designed the study, collected the ticks, extracted DNA of ticks, analysed the presence of pathogens and has written the manuscript, RV has performed statistical analyses and helped with the writing of the manuscript, LPB, DS, JK, GW and ES collected ticks, extracted DNA of ticks and did the molecular analyses of ticks. All authors have read and agreed with the content of the final version of the manuscript.

\section{Acknowledgements}

The study was partially supported by the grant VEGA - 2/0055/-11 and APV-0267-10 and partially funded by EU grant FP7-261504 EDENext and is catalogued by the EDENext Steering Committee as EDENext214. The contents of this publication are the sole responsibility of the authors and don't necessarily reflect the views of the European Commission. The authors thanks M. Stanko and B. Pet'ko for the tick collection in the Czech Republic, L. Vidlička for the help with the figure, R. Ivanová for excellent technical help and S. Barláková for reading the manuscript.

\section{Author details}

${ }^{1}$ Institute of Zoology, Slovak Academy of Sciences, Dúbravská cesta 9, 84506 Bratislava, Slovakia. ${ }^{2}$ Institute of Parasitology, Slovak Academy of Sciences, Košice, Slovak Republic. ${ }^{3}$ Institute of Virology, Slovak Academy of Sciences, Bratislava, Slovak Republic. ${ }^{4}$ Section of Hygiene and Medical Microbiology, Innsbruck Medical University, Innsbruck, Austria.

\section{Received: 2 February 2014 Accepted: 25 March 2014}

Published: 2 April 2014

\section{References}

1. Kawahara M, Rikihisa Y, Isogai E, Takahashi M, Misumi H, Suto C, Shibata S, Zhang C, Tsuji M: Ultrastructure and phylogenetic analysis of "Candidatus Neoehrlichia mikurensis" in the family Anaplasmataceae, isolated from wild rats and found in Ixodes ovatus ticks. Int J Syst Evol Microbiol 2004, 54:1837-1843.

2. Schouls LM, Van De Pol I, Rijpkema SG, Schot CS: Detection and identification of Ehrlichia, Borrelia burgdorferi sensu lato, and Bartonella species in Dutch Ixodes ricinus ticks. J Clin Microbiol 1999, 37:2215-2222. 
3. Andersson $M$, Råberg $L$ : Wild rodents and novel human pathogen Candidatus Neoehrlichia mikurensis, Southern Sweden. Emerg Infect Dis 2011, 17:1716-1718.

4. Jahfari S, Fonville M, Hengeveld P, Reusken C, Scholte EJ, Takken W, Heyman P, Medlock J, Heylen D, Kleve J, Sprong H: Prevalence of Neoehrlichia mikurensis in ticks and rodents from North-west Europe. Parasit Vectors 2012, 5:74.

5. Lommano E, Bertaiola L, Dupasquier C, Gern L: Infections and coinfections of questing Ixodes ricinus ticks by emerging zoonotic pathogens in Western Switzerland. Appl Environ Microbiol 2012, 78:4606-4612.

6. Vayssier-Taussat M, Le Rhun D, Buffet JP, Maaoui N, Galan M, Guivier E, Charbonnel N, Cosson JF: Candidatus Neoehrlichia mikurensis in Bank Voles, France. Emerg Infect Dis 2012, 18:2063-2065.

7. Fehr JS, Bloemberg GV, Ritter C, Hombach M, Luscher TF, Weber R, Keller PM: Septicemia caused by tick-borne bacterial pathogen Candidatus Neoehrlichia mikurensis. Emerg Infect Dis 2010, 16:1127-1129.

8. Welinder-Olsson C, Kjellin E, Vaht K, Jacobsson S, Wenneras C: First case of human "Candidatus Neoehrlichia mikurensis" infection in a febrile patient with chronic lymphocytic leukemia. J Clin Microbiol 2010, 48:1956-1959.

9. Pekova S, Vydra J, Kabickova H, Frankova S, Haugvociva R, Mazal O, Cmejla R, Hardekopf DW, Jancuskova T, Kozak T: Candidatus Neoehrlichia mikurensis infection identified in 2 hematooncologic patients: benefit of molecular techniques for rare pathogen detection. Diag Microbiol Infect Dis 2011, 69:266-270.

10. Burri C, Schumann O, Schumann C, Gern L: Are Apodemus spp. Mice and Myodes glareolus reservoirs for Borrelia miyamotoi, Candidatus Neoehrlichia mikurensis, Rickettsia helvetica, R. monacensis and Anaplasma phagocytophilum? Tick Tick Borne Dis 2014. in press.

11. Richter D, Matuschka FR: "Candidatus Neoehrlichia mikurensis", Anaplasma phagocytophilum, and lyme disease spirochetes in questing european vector ticks and in feeding ticks removed from people. J Clin Microbiol 2012, 50:943-947.

12. Hornok S, Meli ML, Gönczi E, Hofmann-Lehmann R: First evidence of Candidatus Neoehrlichia mikurensis in Hungary. Parasit Vectors 2013, 6:267.

13. Glatz M, Müllegger RR, Maurer F, Fingerle $V$, Achermann $Y$, Wilske $B$, Bloemberg GV: Detection of Candidatus Neoehrlichia mikurensis, Borrelia burgdorferi sensu lato genospecies and Anaplasma phagocytophilum in a tick population from Austria. Ticks Tick Borne Dis 2014, 5:139-144.

14. Courtney JW, Kostelnik LM, Zeidner NS, Massung RF: Multiplex real-time PCR for detection of Anaplasma phagocytophilum and Borrelia burgdorferi. J Clin Microbiol 2004, 42:3164-3168.

15. Massung RF, Slater K, Owens JH, Nicholson WL, Mather TN, Solberg VB, Olson JG: Nested PCR assay for detection of granulocytic ehrlichiae. J Clin Microbiol 1998, 36:1090-1095.

16. Silaghi C, Woll D, Mahling M, Pfister K, Pfeffer M: Candidatus Neoehrlichia mikurensis in rodents in an area with sympatric existence of the hard ticks Ixodes ricinus and Dermacentor reticulatus, Germany. Parasit Vectors 2012, 5:285.

17. Ewald PW: Vectors, vertical transmission, and the evolution of virulence. In Evol Infect Dis. Oxford: Oxford University Press; 1994:35-56.

18. Bown KJ, Lambin X, Ogden NH, Begon M, Telford G, Woldehiwet Z, Birtles R: Delineating Anaplasma phagocytophilum ecotypes in coexisting, discrete enzootic cycles. Emerg Infect Dis 2009, 15:1948-1954.

doi:10.1186/1756-3305-7-160

Cite this article as: Derdáková et al:: Candidatus Neoehrlichia mikurensis and its co-circulation with Anaplasma phagocytophilum in Ixodes ricinus ticks across ecologically different habitats of Central Europe. Parasites \& vectors 2014 7:160

\section{Submit your next manuscript to BioMed Central and take full advantage of:}

- Convenient online submission

- Thorough peer review

- No space constraints or color figure charges

- Immediate publication on acceptance

- Inclusion in PubMed, CAS, Scopus and Google Scholar

- Research which is freely available for redistribution

Submit your manuscript at www.biomedcentral.com/submit
C Biomed Central 